\title{
Parasite Present
}

National Cancer Institute

\section{Source}

National Cancer Institute. Parasite Present. NCI Thesaurus. Code C120903.

Confirmatory presence of parasitic microorganisms. 